\title{
The Feast of Cyril and Methodius in Bessarabia and Crimea, Ukraine
}

\author{
Ekaterina Anastasova
}

\begin{abstract}
Balkan Ethnology Department, the Institute of Ethnology and Folklore Studies with Ethnographic Museum, Bulgarian Academy of Sciences ekaterina_anastasova@yahoo.com
\end{abstract}

\begin{abstract}
The feast of St. Cyril and St. Methodius (May 11-24) and the life and work of the two brothers take a central place in the Bulgarian national paradigm. Their life and work are celebrated by all Slavic nations (with different accents and on different dates in the national/ church calendars). The feast is celebrated among the Bulgarian Diaspora in Ukraine (the largest Bulgarian community outside the Bulgarian boarders) and it has a place in the official state calendar of the country as well.

This paper deals with the celebrations of the feast in Bessarabia (Odessa) and Crimea (Sevastopol), in Ukraine among the Bulgarians and the Ukrainians; the vitas of the two brothers; interpretations of their origin, their works and their significance for the Slavic cultures of both communities (Bulgarians and Ukrainians). The analysis shows the dynamics of interpretations of the lives and the work of the two saints in different national paradigms and state priorities. Key words: St. Clement, St. Cyril and Methodius, Ukrainian Revival, Russia, EU
\end{abstract}

The work of Cyril and Methodius and of their disciples - the creation of the alphabet ${ }^{1}$ and of the Slavic literature language, the translation of Christian sacred books, the spread of Christianity and the introduction of a liturgy in Slavic language - formed the identity of the Slavs in the early period of their history. As stated by N. I. Tolstoy "the creation of the Slavic Alphabet and the Slavic literary language is a new impetus for intensification of the Slavic identity, for understanding the concepts of the place of the Slavs among the other nations" (Tolstoy 1988: 136). The cult of the brothers is renewed during the Renaissance during the process of creation of the modern Slavic nations, becoming central to a number of Slavic national paradigms. This is due to the fundamental nature of the script and the literary culture for the formation of national 
identity, on the one hand, and on the other - to the area in which the two brothers carried out their enlightenment activities. The space, where the idea of Cyril and Methodius is spread, appears to be huge - from Thessaloniki, where they were born ${ }^{2}$, through Chersonesos, Khazaria and Alania, Rome, Moravia, Pannonia and Bavaria to the establishment of literary schools by their students in the territory of modern Bulgaria and Macedonia.

The combination of these factors - the canonization of the two brothers by the Orthodox (Russian Orthodox Church in 1863) ${ }^{3}$ and the Catholic Church (1880), as well as their being proclaimed co-patrons of the United Europe in 1980 by the "Slavic Pope" John Paul II - supported the relevance of the cult of the brothers.

Their veneration is associated not only with the traditional Renaissance contexts, but with a wider European and educated perspective in the new Slavic democracies in the late twentieth century.

The combination of Middle Age, National Revival pathos and postmodern reality defines the two main dimensions of the cult of the two brothers relevant in the context of this article:

1. The forms of their ritual worship (the feast of St. Cyril and Methodius): the religious and the secular, i.e. - official/national day of "education and culture" (Slavic, Bulgarian, etc.) and of school, a children's holiday;

2. The use of the cult of the two brothers in various political and geopolitical contexts.

Here we will focus on the idea of "Cyril and Methodius" in Ukraine from two main perspectives: the cult and the feast as a part of the Ukrainian national culture and the culture of the Bulgarian diaspora within the country (the largest traditional Bulgarian diaspora abroad). This article has been assembled on the basis of field research conducted in the cities of Odessa and Sevastopol in the year 2009 and the current dimensions of the cult of Cyril and Methodius in contemporary Ukraine (2014). 


\section{Historical Context: Ukraine between East, West and Multiethnicity}

Ukraine is one of the most complex post-soviet counties regarding internal tensions and geopolitical orientation. The historical circumstances determine various trends and moods in the second largest country in Europe. The etymology of the historical names of the country is based on the idea of a "borderline": Ukraine ${ }^{4} y$-края ('in-the-end', 'at-the-end', 'at-the-border'), Malorussia (Malorosiya 'Small Russia') ${ }^{5}$, Novorussia (Novorosiya 'New Russia').

S. Huntington defines Ukraine as belonging to the so-called "countries of the fault" in the frames of the geopolitical structure separating the world into civilizations, concentrated around core-states. Europe, in his opinion (and not only his), is divided into Western (Western-Christian) and Eastern (Orthodox and Islamic). Within this concept Ukraine is divided into Western: Uniate ${ }^{6}$, Ukrainianspeaking and "nationalist"; and Eastern: Orthodox and Russianspeaking. The first aims at the West, and the second at Russia, the state-core of the Orthodox world (Huntington 1999: 220-238). After the dissolution of the USSR, Ukraine is one of the most "volatile countries" regarding its geo-political orientation (Anastasova 2012: 269-278).

The debate regarding the orientation of Ukraine (towards Russia or the European Union) appears to reach its highest level in parallel with the orientation of each newly elected Ukrainian government. Ukraine was in a situation of forthcoming elections in the year 2009 when I conducted my study. 2013 the confrontation between the pro-European and pro-Russian orientations of Ukraine led to the failure to sign the Association Agreement to EU which led to the events of the Maidan, and the long and bloody civil war (2014).

The multiethnic character of the country is included in the complex geopolitical context. After the fall of the USSR and its construction as an independent nation, Ukraine chooses the ethnic concept of nation, i.e. differentiating national (in Ukrainian terminology national-cultural) minorities who receive (although minimal) statefunding for their activities (Anastasova 2005: 59-65). Besides the main ethnic (and linguistic - as far as Russian language being predominant in the cities) opposition between Russians and Ukrain- 
ians (in $2001-77.8 \%$ Ukrainians, $17.3 \%$ Russians), the complex attitudes of the Ukrainian population are associated with the large multiethnic areas of the country such as our main focus of interest - Bessarabia and the Crimea.

In Bessarabia, a region of Odessa, 123 ethnic communities have been registered $^{7}$, at the same time the traditionally Russian-speaking Crimea (Autonomous Republic since 1991) not only experienced dramatic "Ukrainization", but also the return of the Crimean Tatars deported by Joseph Stalin after World War II and rehabilitated in the period of the "Perestroika" of Mikhail Gorbachev.

Both in Bessarabia and Crimea, the Bulgarians appear to be a significant national minority (according to the census of 2001, the number of Bulgarians in Ukraine is over 200,000 and they live mainly in the Odessa and Zaporozhye regions). The Bessarabian Bulgarians are dominant in both areas due to the fact that after the deportation from Crimea only a small part of the Crimean Bulgarians returned. The Bulgarians are involved both in the common Ukrainian political debate as well as in the process of revival of ethnic minorities in the post-Soviet space (Anastasova 2012). A number of Bulgarian ethnic organizations exist in Ukraine, the Bulgarian language is taught in schools and universities, Bulgarian books and newspapers are being published.

Both processes - the establishment of an independent Ukraine and the "re-birth" of the minorities - generate an intense "new understanding" of the past (the "own history" - national and ethnic) and a culture of the state which, following the logic of the nation-building process, is reflected mainly in the school textbooks and curricula. The desire to disengage from the Russian (Soviet) history and historiography leads to new interpretations that reflect the moods within the country. One can cite a number of examples (reformulation of "heroes" and "anti-heroes", "war of monuments", etc.). As summarized by V. V. Kerov:

After the collapse of the USSR [into former Soviet republics note by E. A.], own national history textbooks are very quickly written... [---]. The first editions are not created on the basis of the achievements of the own new academic science. [---] Later, based on the development of the academic research 
and, more accurately, on the interpretation of known facts, new original textbooks are written. With varying degrees of detachment from the historical reality and the intensity of the anti-Russian sentiments, the authors of these books begin to form often mythologized ideas of historical processes of the territories which received new statehood.

In the new educational literature of Ukraine fragments of the Russian history begin to be coloured in Ukrainian tones. Thus, Yaroslav the Wise, Vladimir Monomakh and other princes of Kiev spoke the "ancient Ukrainian language" [---]. In general, often even in X-XII centuries the culture of the Russia-Ukraine is talked about in synchrony with the concept of M. S. Grushevsky. The sections "Ukrainian Literature" mention such activists of the "Ukrainian literature" as Theophanes Prokopovich, Dmitry Rostovski, scientists and educators, including the author of the first Russian textbook on mathematics L. Magnitsky, the philologist I. Sreznevski, and others. Naturally, Ivan Fedorov was the first Ukrainian publisher, etc. (Kerov 2013: 124-124)

The brothers Cyril and Methodius also fit within the context of Ukrainization and the ideologeme of Slavic unity. As in most countries, in Ukraine their heritage also has its history and geography. In the Odessa region, and especially in Crimea, it begins with the story of Clement of Rome as presented by Legenda Italica ('Italian legend').

\section{St. Clement of Rome, Constantine ${ }^{8}$ (Cyril) and Methodius in Crimea}

According to the vita of Pope Clement I (Bishop Clement of Rome), Christian martyr, preacher and writer who died about $101 \mathrm{AD}$, he was baptized and ordained by the Apostle Peter himself. His life and worship are related to the Roman Church, Crimea and Kievan Rus.

The story of Clement of Rome described in his vita coincides almost word for word with the stories told by respondents in Sevastopol who are familiar not only with the story but its Crimean topography also - as well as with the story presented by the official Ukrainian concept today. 


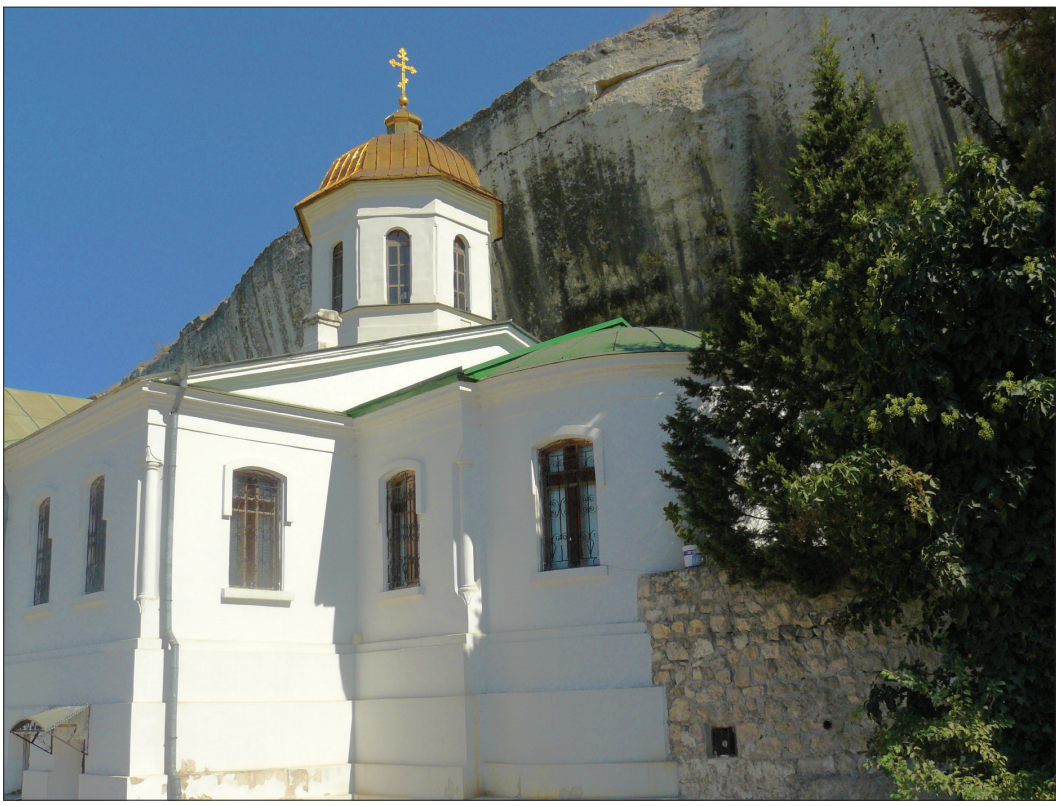

Figure 1. Saint Clement Monastery in Inkerman town, Crimea. Photo by E. Anastasova, 2009.

Due to his preaching and baptising activities in Rome, Clement was exiled by the Emperor Trajan to the marble quarries of Inkerman (now the city of Inkerman which is located near the Chersonesus Tauris/Korsun, Crimea ${ }^{9}$ ) where he continued to preach, to destroy pagan sanctuaries and to perform miracles. Thus, with the help of an Angel of God who manifests himself as a lamb, the saint discovered a water source for the thirsty stonemasons. After that he began to baptize about 500 people daily. The enraged emperor sentenced Clement to a painful death - to be tied to an anchor and drowned in the sea. After the execution of Clement, thanks to the prayers of his disciples, the sea opened every year for a week and revealed the magnificent marble tomb of the saint close to which one could see the anchor with which he was drowned. The believers walked through the withdrawn sea and worshiped the saint. A number of miracles were performed near the tomb - healings, expulsion of 
demons, etc. This miracle continued to happen throughout a total of seven centuries.

In $860 \mathrm{AD}$ Constantine the Philosopher was sent to Khazaria, a neighbouring country of Byzantine where three religions existed equally: Judaism, Christianity and Islam, many pagan cults being present as well as; in order to convince the Khazarian Hagan to convert to Christianity. He went together with Methodius stopping for almost a year in Chersonese Tauris (near the today's city of Sevastopol) where he studied Hebrew in order to take part in theologi-

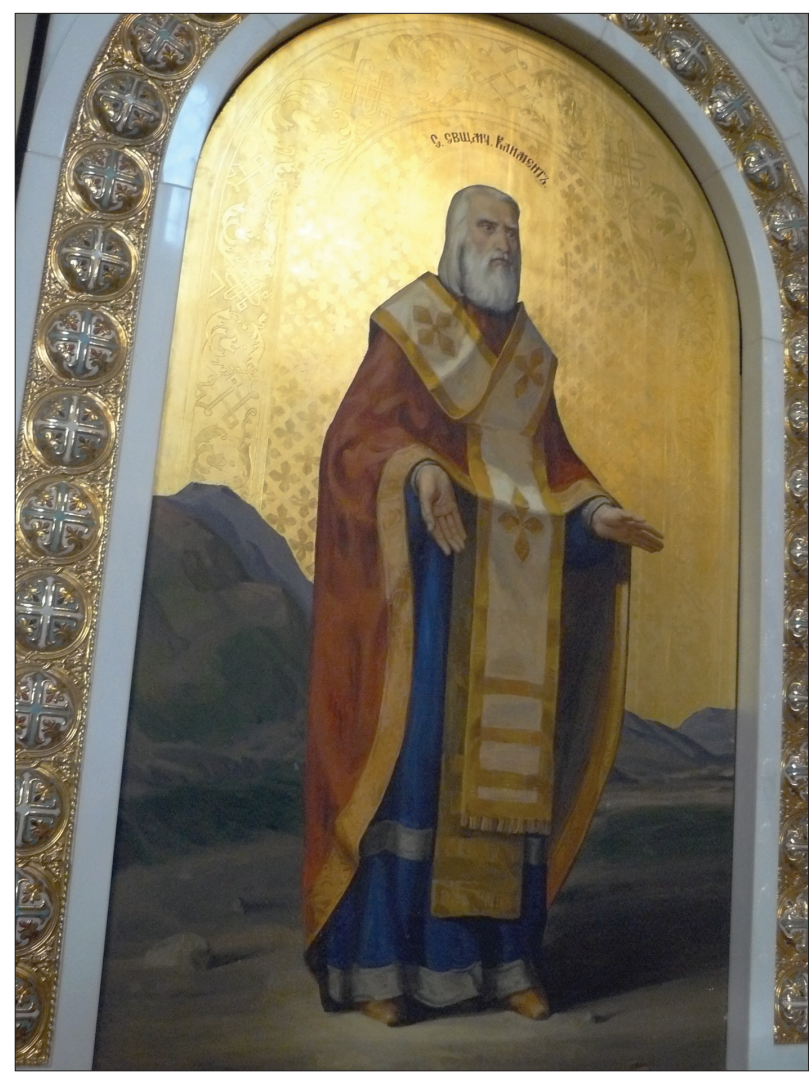

Figure 2. Mural painting of St. Clement, in St. Knyaz Vladimir Church, Hersonissos of Tavria, Sevastopol.

Photo by E. Anastasova, 2009. 


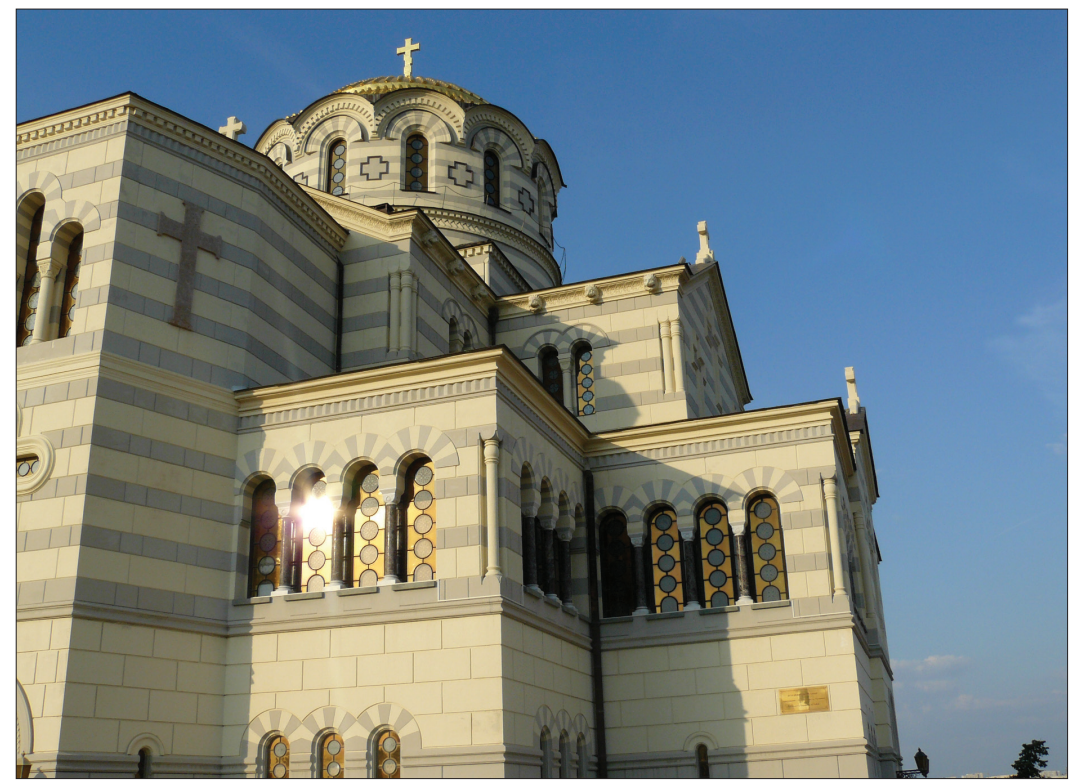

Figure 3. St. Knyaz Vladimir Church, Chersonesus of Tauria, Sevastopol. Photo by E. Anastasova, 2009.

cal disputes with the Khazarian priests. Arriving in Chersonesus, Constantine did some research trying to reveal the location of the saint's tomb and, accompanied by a solemn group of enthusiastic local clergy and laity, on January 30, 861 he discovered the first rib and later the intact relics of the saint ${ }^{10}$. After the Moravian mission the brothers moved the saint's relics to Rome (in $868 \mathrm{AD}$ ). His head remained in the Chersonesus. Later, after being converted to Christianity in Chersonesus, the great Kiev Prince Vladimir (c. 96-1015), the baptizer of the Russian state, carried the head of Clement to Kiev.

This event plays a major role in the worship of St. Clement and St. Cyril and Methodius in the cities of Sevastopol, located near the ruins of Chersonesus Tauris, and Inkerman. The popularity of Cyril and Methodius is overshadowed by that of St. Clement, who appears to be highly honoured by the inhabitants of the Crimea. 
According to the experts, the story of St. Clement is quite different. Obviously, the cult of Clement of Rome revived by Constantine the Philosopher is superimposed on the existing local cults. The worship of the local Clement (from Chersonesus) is intertwined with the cult of Clement Ankirski1 (from Ankara), buried in Ankira (in Galatea) where, according to the Byzantine tradition, Clement of Rome died. Relics of Clement of Ankira were taken to Chersonesus. The pagans threw them into the sea and the relics continued performing miracles. There is no conclusive historical evidence that St. Clement of Rome was martyred (but he did not die in his bed, as indicated by earlier sources) and that he was ever in the

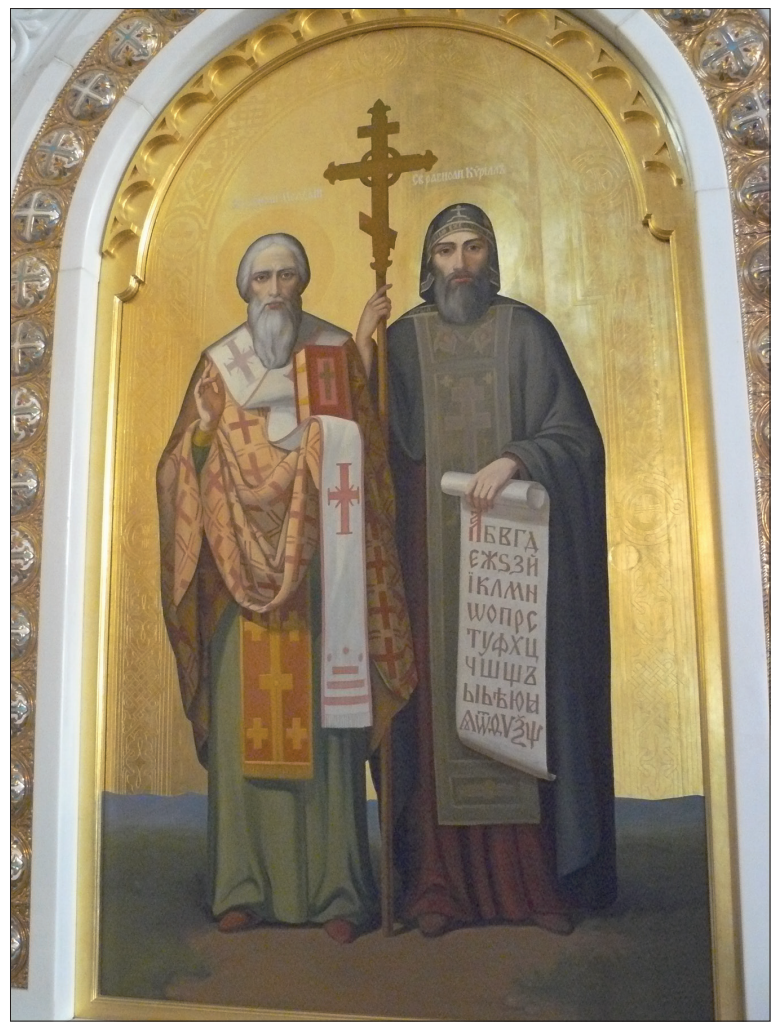

Figure 4. Mural painting of Sts. Cyril and Methodius in St. Knyaz Vladimir Church. Photo by E. Anastasova, 2009. 
Crimea (see for instance the history of the formation of the life of St. Clement of Rome in Spiridonov ${ }^{12}$ 1909: 115-124).

Today the cult of the saint continues to be extremely popular among the residents of Sevastopol, the presumed site of his death is honoured, as well as the so called Kazachiya Bay in Sevastopol (supposed place of St. Clement's death). ${ }^{13}$ The St. Clement cave monastery in Inkerman is highly visited, the dried up (during the 70 s of XX century) spring in its yard is considered to be the water source discovered by the saint.

The vita of Clement of Rome connects the history of the Eastern and the Western Christian church in contemporary Crimea, Ukraine and Russia in an interesting way outlining the later geopolitical "rift" (in the terminology of Huntington) features of the region.

As expected, the nation-building process encompasses the sacred "nationalization" of Christian saints of Ukraine and Russia. Thus, August 22, 2011 a memorial cross in honour of St. Clement was sanctified in the courtyard of the temple of the holy Clement of Rome in Zamoskvorechie (Russia). It was financed by the Fund of the Reverend Andrei Rublev with the blessing of the Metropolitan of Simferopol and Crimea Lazar. As reported by the Center Gumilyov (Contemporary Eurasianism, Movement for the Protection of the Rights of Peoples ${ }^{14}$ ), at the opening of the cross the officer of the church, Father Leonid (Kalinin), said:

The establishment of a memorial cross has no political connotations. This is a purely spiritual action expressed in the triumph of the historical justice and a reminder of the common Slavic spirit of Ukraine and Russia.

The author of the text continues:

Let us remember that Clement was the fourth bishop (Pope) of Rome ordained by Apostle Peter himself. St. Clement is considered the patron saint of Russia. To him people pray for the health and the welfare of their children, for family reunification, for the return of loved ones. ${ }^{15}$ The relics of the martyr Clement are the first Christian sanctified objects to appear in Russia. The Holy Prince Vladimir converted Russia with the honest head of St. Clement in 988. 


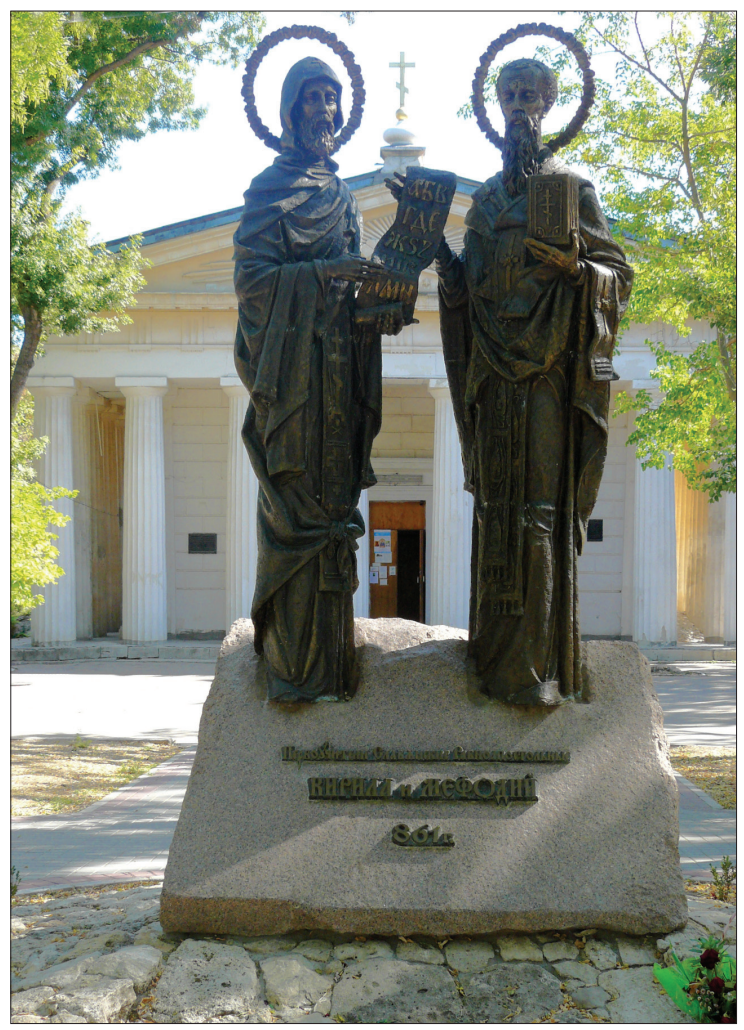

Figure 5. Monument of Cyril and Methodius in Sevastopol, Crimea. Photo by E. Anastasova, 2009.

Without doubt "the common Slavic spirit of Ukraine and Russia" is a part of the big discussion "Russia or Europe" which continues to worry the Ukrainian society.

Compared to the figure of St. Clement of Rome in Crimea, the place of Cyril and Methodius is more modest. A monument of the saints was built as late as 2008 in Sevastopol, on June 14 , the day of the city (until then there is no object named after the saints in the city) on the initiative of the City Hall with participation of the national and cultural center of the Bulgarians in Sevastopol - the organization "Izgrev" (Sunrise). 
At the opening of the celebrations V. Kazarin, the first vice-chairman of the city administration, says:

The Slavic alphabet was created 1145 years ago. Cyril and Methodius display it written in Moravia, but their idea dates back another two years, $861 A D$, when, while being in Chersonesus, they were introduced to one of the oldest script systems, which has not survived to our day. Their alphabet was a combination of the spirit of the Greek alphabet with the spirit of this ancient alphabet. [---] Our city can be proud that it is not only the cradle of Orthodoxy of the Eastern Slavs, due to the baptism of St. Vladimir in Chersonesus, but that Sevastopol is also the cradle of the Slavic script. ${ }^{16}$

However, for the Ukrainians, as well as for the Bulgarians in Sevastopol, the worship of St. Clement continues to play a leading role - they regularly pray, donate funds and support the creation of a new additions to the rock monastery in Inkerman; they plan the erection of a chapel or a memorial cross in Kazachiya Bay. As the chairman of the Bulgarian organization in Sevastopol claims:

Here in Crimea the most famous saint is Clement of Rome (and his story). Last year we built a monument of Cyril and Methodius on May 24, we left flowers; the people are not so familiar with these saints though. St. Clement is a local saint, which is why people know more about him here. ${ }^{17}$

Actually, the honouring of the brothers Cyril and Methodius is part of another paradigm, related to the national idea of the history and their activity in Ukraine.

\section{National Dimensions}

In Ukraine, as well as in Bulgaria, the feast of the holy brothers has two dimensions: secular feast and church (religious) celebrations.

In Bulgaria, the cult of the brothers was formed and established in the process of the Bulgarian Revival and it is based on three main "fundaments" related to the Bulgarian national idea: 
1. The medieval majesty of Bulgaria, the so-called "Golden Age" of the Bulgarian culture, and the fundamental role of the Bulgarian state in the formation of Pax Slavia Orthodoxa;

2. The Bulgarian contribution to the development of the European civilization;

3. The Bulgarian revival and the creation of modern Bulgarian state.

The feast is so popular that the question about its establishment as a national feast has been risen within the Bulgarian media space in the last years.

However, the situation in Ukraine is different. The roots of the worship of brothers Cyril and Methodius are associated with the Slavonophile idea and messianic role of Russia in the Slavic world, on the one hand. On the other hand, we find the ideas of the "Brotherhood of Cyril and Methodius", a secret political organization which emerged in Kiev in the late 1845 to early 1846 and lasted only 14 months. The Brotherhood is considered the first Ukrainian political organization through which the Ukrainian intelligentsia attempts to fight for the rights of the Ukrainian people. The organization follows the ideas of Russian Decembrists (dekabristy) but calls not only for the repeal of serfdom and the liberalization of the political system, but also for a national and cultural identity of the Slavic peoples, united in a common Pan-Slavic Federation under the leadership of Kiev. Ukraine, Russia, Poland, Serbia and Bulgaria are supposed to become members of the Pan-Slavic Federation. The organization originated from the Kiev University and has about a dozen members, including the classic of the Ukrainian literature Taras Shevchenko. The Brotherhood's program's documents - "Act of God. Book of life of the Ukrainian people" and "Statute of the Slavic Society of St. Cyril and Methodius" (Statute of the Slavonic Society) - written by the founder of the organization, the future professor of history, N. I. Kostomarov (at the moment assistant professor at the Kiev University) are considered the beginning of Ukrainophilia (see further details in Zayonchkovskiy 1959, Simonova 1990: 341-366) or-Ukrainian nationalism. One of the members of the organization, Panteleimon Kulish, is the author of the first history of Ukraine (Po vest' ob ukrainskom narode, 1846) and of the first grammar of the Ukrainian language. In other words, the Brotherhood of the St. 
Cyril and Methodius, despite its short existence (later its activity is depicted as Slavonophilic by the movement of the Russian imperial propaganda) marks the beginning of the Ukrainian revival.

Obviously, the Cyril and Methodius's idea, since its origination in Ukraine, is connected to the national, political and state messages, especially during the current geo-political challenges. The religious organizations are a space for political messages as well. After the democratic changes the religious space in the country is divided also: the majority of the churches in Ukraine are subordinate to the Moscow Patriarchy (Ukrainian Orthodox Church of the Moscow Patriarchate) and the new Ukrainian Orthodox Church of the Kiev Patriarchate (separated from the Moscow Patriarchate in 1992), which enjoys considerably less influence.

Celebrations of both the secular and the religious feasts take place on May 24. The celebration began in 1994, following a proposal by the Ministry of Culture and the Ukrainian Committee of the Slavists, supported by the Cabinet of Ministers of Ukraine. The celebration was established as a public holiday by the Decree of the President Leonid Kuchma in 2004.

We should note, in the context of the nation-building process, that in Ukraine, as well as in the whole post-socialist space, there is a process of updating the national, the official and the religious holidays to reflect the new ideological and political situation (Anastasova 2012a, 156-169). So, for example, in addition to May 24, post-socialist Ukraine celebrates the Day of the Ukrainian script and language on November 9 in honour of Nestor the Historian, considered by the new Ukrainian science to be an Ukrainian historian and follower of the brothers Cyril and Methodius. The feast is celebrated as a state holiday since 1997 in accordance with a decree by the president Leonid Kuchma in an "answer to initiatives of social organizations and considering the important role of the Ukrainian language for the consolidation of the Ukrainian society" (Decree 1241/97, 06.11.1997.).

In addition, one can include in the series of celebrations related to the Slavic culture the Day of Friendship and Unity of Slavs which takes place on June 25. It was established during the 1990s "as a response to the collapse of the USSR" and is celebrated in Russia, 
Belarus and Ukraine. The cultural festival "Slavic Unity" (in the town of Bryansk, Russia) is held on that date as well. The feast was established on the basis of the International Festival of Slavic Youth (which in the USSR took place annually since 1957 - USSR Festival Movement "Malaya Rodina"). 2002 the festival presented a declaration to the governments of Russia, Belarus and Ukraine for a referendum aimed to merge the three countries. In all of them the feast is presented as a peculiar "conclusion" of the celebrations of the Day of Cyril and Methodius.

The messages of the three feasts are obvious - from the national one in the case of the Day of the Ukrainian literature and language, through the pan-Slavic, to the honest request to merge the three Eastern Slavic countries. Naturally, the holidays and the messages are being used in different political situations. For example, during the Day of Friendship and Unity of Slavs, celebrated mostly in the Eastern, Russian-speaking regions of Ukraine, a deputy of the proRussian Party of the regions Vadim Kolesnichenko says:

It is highly important that Ukraine celebrates the Day of Friendship and Unity of Slavs on the threshold of the second reading of the law dealing with the foundations of the state language policy. [---] This holiday is very important because of the fact that it unites Slavs with different cultural backgrounds. It is a further reminder that we can and must speak different languages, including Russian and Ukrainian. And it should not cause anything but mutual respect, mutual support and mutual joy that we have such deep roots - not only historical, but also humanitarian and linguistic. (the Party of Regions is an importer of the law, confirming the status the Russian language as a regional language $)^{18}$

On the Day of Nestor the Chronicler, flowers are delivered to the monument in Kiev, solemn words are uttered, the "best promoters of the Ukrainian word" awarded and publishers, who publish in Ukrainian language, encouraged. Around the period of the feast, an International Competition of connoisseurs of the Ukrainian language "Petro Yatsik" is organized. The competition was for the first time organized in the year 2000 under the patronage of $\mathrm{Na}$ dezhda Yatsik, daughter of P. Yatsik (a Canadian businessman, ethnic Ukrainian, patron and philanthropist ${ }^{\mathbf{1 9}}$ ), and the Educational 
Fund "P. Yatsik" headed by her. 2006 the fund withdrew from the competition with a declaration by N. Yatsik that "the Ukrainian diaspora cannot save the Ukrainian language in Ukraine. This can only be done by the Government of Ukraine".

The celebration of the brothers Cyril and Methodius in the capital Kiev, as well as in cities that have their monuments (Kiev, Odessa and Sevastopol), follows a similar pattern. The festivities dedicated to the brothers are, among others, visited by representatives of the Bulgarian diplomatic services (see below). Among the accompanying events we can mention the school holidays in the ethnic Bulgarianpopulated villages (in Bessarabia, Crimea, Azov region), conducting quizzes, contests and competitions. Students of Bulgarian ethnic origin also participate in university competitions and celebrations organized by the Bulgarian national-cultural societies. As part of the celebration "Cyril and Methodius readings" (Kirillo-Mefodievskie chteniya) are held in various cities in Ukraine.

Probably the deepest traditions of honouring the brothers Cyril and Methodius are observed in Odessa, where the roots of the celebration are religious and date from the late XIX to early XX century. Today the feast in the city has three basic forms:

1. Religious - a patron feast of two churches in the city;

2. Ten-day festival of the Bulgarian culture, organized by the Bulgarian diplomatic corpus, celebrated around May 24 in Odessa;

3. Feast of the Bulgarian diaspora - a school holiday in the villages with ethnic Bulgarians in the Odessa region and within the celebrations performed by the Bulgarian organizations in the area, supported by the Consulate of the Republic of Bulgaria in the city (exhibitions, concerts, academic conferences, quizzes, etc.)

The city has a monument to the holy brothers, inaugurated on May 24, 2007. As stated during its inauguration the "monument symbolizes the friendship between Ukraine and Bulgaria". It is situated in front of the Humanitarian corpus of the Odessa National University, where such Bulgarian national poets as Ivan Vazov and Hristo Botev studied and these days dozens of students with Bulgarian ethnic origin are being educated. 


\section{The Odessa Spiritual School}

The temple of the St. Cyril and Methodius, educators of the Slavs, was built in Odessa as a school church of the Odessa spiritual school in 1882. Since its establishment the temple has been extremely popular among the laity:

Although a Cathedral of Peter and Paul was located nearby and the Temple of Ascension stood at the intersection of Staroportofrankovska and Kolontaevska street, the temple of the St. Cyril and Methodius was always full of people. During the holiday the church could not accommodate all worshipers of St. Cyril and Methodius because they are considered to be guardians of students and patrons of children. (Anisimov 2005: 23)

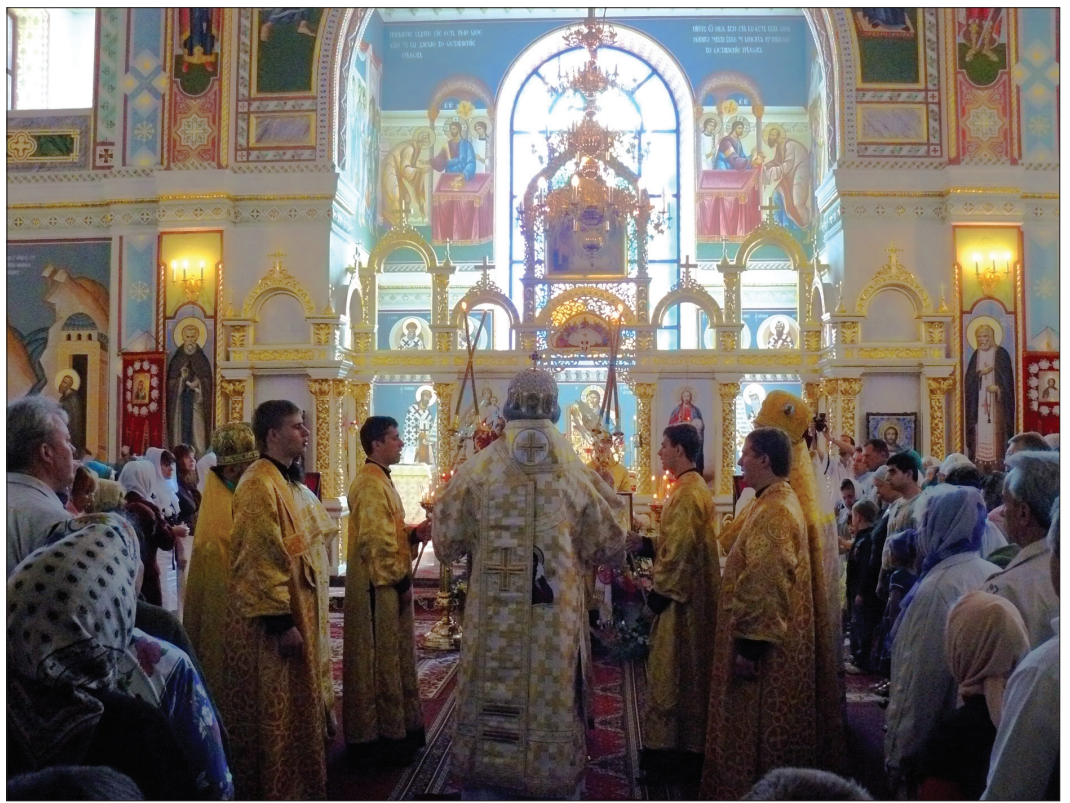

Figure 6. Sts. Cyril and Methodius Church (interior), old Spiritual School, Odessa. Photo by E. Anastasova, 2009. 


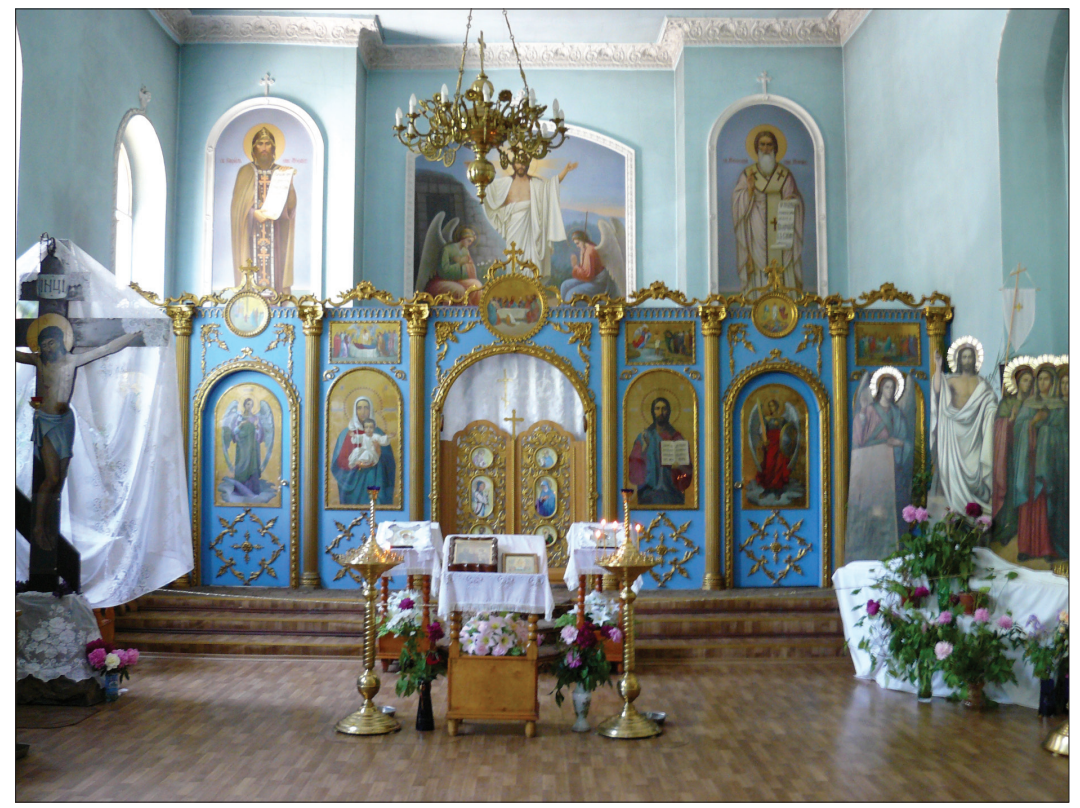

Figure 7. Church service in honor of Sts. Cyril and Methodius with Bishop Agafangel. May 24, 2009, Odessa Military School. Photo by E. Anastasova.

The temple has a complex history; it has been closed and re-opened several times. In 1933 its "religious valuables in favour of the state" are seized, the church - closed but not destroyed as being part of a building (unlike the two churches mentioned above). During World War II it was opened again during the Romanian government and finally closed in 1953 when the Soviet government turned it into a sports hall.

The temple was restored gradually, beginning from May 24, 1996 until May 24, 2003 (Anisimov 2005: 30).

Today, just as when it was founded, the temple is a "neighbourhood church" visited by representatives of a number of Orthodox denominations in the city - Russians, Ukrainians, Greeks, Bulgarians, etc. 


\section{"The Military School" - Politics and Belief}

The temple of the saints Cyril and Methodius belonging to the "military school" has a long history. Initially the temple dedicated to the holy brothers, patrons of science, was built in Odessa cadet corps (created by the order of the Russian Emperor Nicholas II in 1899) and inaugurated in 1902. In 1917 it was turned into a School of the Military Office. From 1941 it became the Odessa infantry school and after its demise - a part of the Odessa Polytechnic University (established in 1918) as Military Institute. Both during the socialist period, when the institute is one of the most prestigious military schools in the USSR, and today the Military Academy of the Army (2011) is the centre of the military elite and the military clergy (clergy to churches and chapels of military service) in the region.

\section{The Patron Feast of the Church St. Cyril and Methodius at the Odessa Academy of Land Forces}

Solemn liturgy performed by one of the most respected personalities in Ukrainian clergy, the Bishop of Odessa and Izmail area, Bishop Agafangel and the following lunch for all the participants (teachers and students of the school) are the feast of the Russian speaking society in Odessa (Odessa is a traditional Russian-speaking city). Ethnic Bulgarians do not attend the feast and, as it turns out, rarely visit this temple.

Bishop Agafangel (Bishop of Odessa and Izmail Diocese since 1992) is not only a spiritual person but also very active publicly and politically. During the period 1990-1994 he is a popular member of the Ukrainian Rada and in 2006 heads the list of the Odessa region of the pro-Russian "Party of Regions" being its representative in the District government during two consecutive mandates ${ }^{20}$. He is one of the fiercest opponents of the schism of the Ukrainian Orthodox Church (the separation of part of the clergy from the Moscow patriarchy). The cleric is a bright figure in the political life of the Odessa region whose public statements shape the public opinion. The authoritative words of the Russian journalist and chief editor of Radio "Echo of Moscow", Alexei Venediktov, are a testimony of the personality of the bishop and his influence on the Odessa public: "This is a man of firm principles and of great charisma. I 
think that the victory of the "Party of Regions" in the Odessa area is undoubtedly his merit." 1

Agafangel always comments on current events related to the opposition Russia-West (understood as EU and NATO) in Ukraine:

The Orthodox Church is worried by the involvement of Ukraine in the Alliance (NATO) which appears in its essence to be a beast organization [emphasis mine-E. A.], professing double standards. [---]

The schools teach the children that the Alliance will turn us into a European country although we are in the centre of Europe. We have a lot to teach our children too, we have culture, religion, moral principles. [---]

We see the actions of this unit in Kosovo, we see what is being done to Russia. NATO - it is blood, war and tears. ${ }^{22}$

His are the statements, often discussed as "scandalous", that "the USSR is the homeland of us all" as well as that "Lvov"23 is our Chechnya"24.

He includes the actions of Cyril and Methodius in a current political context during his festivity sermon in May, 2009:

Cyril and Methodius bequeathed the brotherhood to the Slavic people ... Today we lift our prayers to the throne of God. The saints Cyril and Methodius prayed with us. We pray to God to strengthen the unity of our fraternal Slavic people, to prevent the hostile forces from causing conflicts among the people of Ukraine, Russia and Belarus. And we believe that through the prayers of these holy saints - educators of the Slavs, our peoples will safely survive the current hard times and the evil, who try to re-write our history, will withdraw. Their time is over. Soon new forces will come that will stop this vicious practice of sowing enmity among the people of Russia, Ukraine and Belarus. All of us - Russians, Ukrainians, and Belarusians have received Holy Baptism in one "Dnieper river font". We share one Orthodox faith, one culture, one history. ${ }^{25}$

Those words proved prophetic given the victory of the Party of Regions in Ukraine in the 2009 elections. 


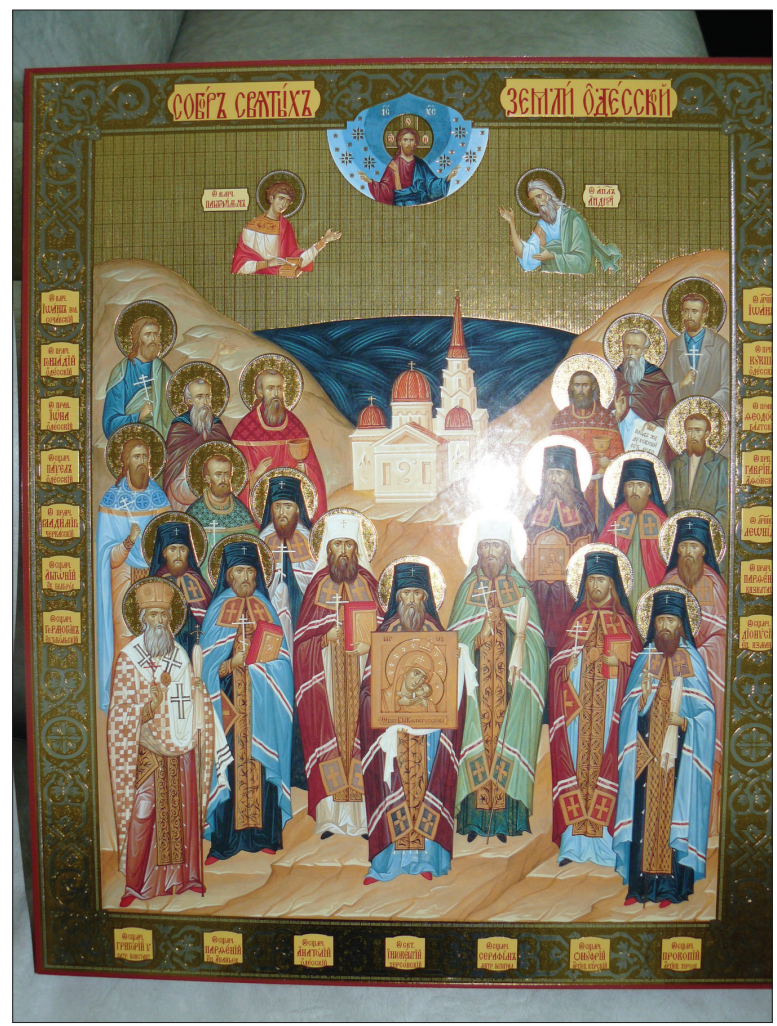

Figure 8. Icon of new Odessa saints. Photo by E. Anastasova, 2009.

If for the bishop and the military elite the holy brothers are symbols of current political messages, for the laity (part of the religious and military elite) the feast of the saints possesses another meaning. On the one hand, they are seen as patron saints of those named after them, they celebrate their name-day (angel-day) on this date (or of those whose relatives visit the temple to remember them if they are deceased). The temple is visited by the people whose relatives died on the day of the holy brothers in order to ask them to protect their beloved ones before God. On the other hand, the majority of participants consider Cyril and Methodius first of all saints: 
1. Patrons and protectors of the Slavs;

2. Creators of the most understandable and close (directly reaching) to God language - the Slavic language.

This perception of the saints is associated with mediation and advocacy in the relations between a person and a nation - God is not at the forefront both in mass (secular) Bulgarian discourse as well as among the young ethnic Bulgarians in Odessa. ${ }^{26}$ The latter rather indicate the enlightenment functions of the brothers - their being the creators of the Slavic alphabet. Although maintaining close relations with the Bulgarian Consulate in Odessa, which manifests the Bulgarian national thesis about holy brothers, whose work "makes every Bulgarian proud for giving something so significant to the world"27, for the young Bessarabian Bulgarians the figures of Cyril and Methodius carry various massages. Along with the traditional notions of "creators of the Slavic alphabet" and "It's good that they have created the alphabet" there are present other statements such as: "Cyril and Methodius were Slavs, they were not Bulgarians" and surprisingly: "Perhaps it would have been better not to create this alphabet - these oppositions would not have existed now: EuropeRussia, Latin-Cyrillic... And we would have been more united."28

\section{Conclusions}

Since the beginning, the work of Cyril and Methodius, as well as its update within the Slavophilism and the construction of various nationalisms during the formation of the modern Slavic states in the nineteenth century, has a political nature. Interestingly, in the post-modern period, during a geo-political upheaval, it resumes its political dimensions not only in the state but also in the religious aspect. The brothers are used as an argument to prove an opposite thesis: for Bulgaria, a country member of the European Union, they are part of the European cultural heritage; for Ukraine they are a symbol of national revival and an argument for brotherhood with Russia and the Slavic countries opposed to NATO, EU and USA.

2014 the long lasting protest - "Euromaidan" in Kiev (which began on 21.11.2013), a protest that arose as a result of the suspension of negotiations with the EU and the refusal of the president $\mathrm{V}$. Yanukovych to sign the Association of Ukraine to the European 
Union agreement at a meeting of the "Eastern Partnership" in Vilnius - the subsequent political crisis, the accession of the Crimea to the Russian Federation, and later the bloody civil war became a major world news. One of the main characters in this article - the Metropolitan Agafangel reappeared on the scene. In honour of the arrival of the relics of St. George in Odessa he says in a sermon:

The right hand of St. George arrived in Ukraine at a moment when the confusion and especially the Kiev Maidan, where the forces of hell gather to destroy our system, import confusion, hatred and division among our people ... but, with the help of the prayers of the saint, God will admonish the foolish, bring peace and harmony to the society ... We believe that the stronger forces will win. ${ }^{29}$

In the statements of the Ukrainian hierarchs the political, social and economic crisis receives apocalyptic dimensions:

We know that the first revolutionary was the devil, the revolutions are performed by the forces of hell. The call of Europe today is named by the Orthodox Eurosodom. Europe imposes violation of our Christian values, implements mandatory same-sex marriages [---], perverted education of the children at school, and most importantly - forces us to go out of the Orthodox civilization and become a suburb of the Protestant-Catholic civilization and today aggressively secular anti-Christian organization, where an important force is the aggressive Islam. I believe that the real Europe, the Christian Europe was preserved only in Russia. And only together with Russia can Belarus, Ukraine and Moldova become the core of the Orthodox civilization, which will stop the lawlessness that reigns in the world. ${ }^{30}$

Obviously, the "civilizational" terminology of S. Huntington is close to the pro-Russian Ukrainian clergy who sanctified the geopolitical confrontation using fundamental religious opposition Lord - Devil (Russia, the Orthodox world - EU).

A medieval technique is used, which, relying on the historical destiny, the ethnic tensions, and the post-Soviet nostalgia in Ukraine, outlines an ambitious postmodern project. A project in which Cyril and Methodius, the "unifiers of the Slavs", find their place again. 


\section{Notes}

1 The Glagolitic alphabet (Glagolitsa).

${ }^{2}$ One should mention the monasticism of Methodius in the area of today's Turkish city of Bursa, his exile in Germany (medieval Swabia), etc.

${ }^{3}$ According to a number of records the holy brothers were canonized by the Bulgarian church already during the Middle Ages.

${ }^{4}$ The word Ukraine appears first in the Ipatiev Chronicle (1187). According to another etymology Ukraine comes from the Ukrainian substantive краіна and means 'country'.

${ }^{5}$ Geographical term used in XIV-XV centuries in connection with the Kingdom of Galytsia-Volyn Principality (Galitsko-Volynskoe kniyazhestvo) and since XVI century in connection with the lands of south-western Russia. From XVII to early XX century, it is used in Russia as a name for the geographic region and province Malorosiya (Malorossiyskaya guberniya). The term Ukraine was approved in the USSR.

${ }^{6}$ Uniates practice Orthodox church service but the church is under the rule of the Pope.

${ }^{7}$ According to the data of the administration of the Odessa region from September 2013 (International Research and Practice Conference "Polyphony vs. cacophony: Ethnic and Confessional Diversity of the Population of Odessa Region in the Context of Regional Democracy", September 12-14, 2013, Odessa State University, Odessa, Ukraine).

${ }^{8}$ Still with its secular name during the founding of the relicts of St. Clement.

${ }^{9}$ Excavations have proved that there were no marble quarries in this area.

10 The description of these events appears in "Word for Carrying the Glorious Relics of Clement" which is attributed to St. Cyril, see for example Begunov 2006: 5 .

11 The name of ancient Ankara.

12 The story of Dimitriy Spiridonov (1871-1938), a thorough researcher of the figure of the "Crimean" Clement, an university professor, authoritative Byzantine specialist, clergymen, is tragic. He was shot by the Stalinist regime in 1938, in 2000 was canonized by the Russian Orthodox Church at the proposal of the Crimean diocese. He is celebrated on the day of the Festival of Russian new martyrs and confessors (the first Sunday of the period 25.01-07.02). 
${ }^{13}$ The story of the "search" of St. Clement in Crimea according to historical, literary and archaeological data is very interesting. See for example: Markevich1909: 106-114; Sorochan 2013: 205-225, 240-278.

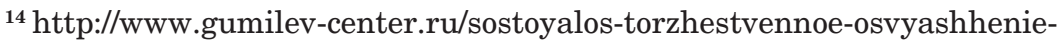
pamyatnogo-kresta-v-chest-pervogo-russkogo-svyatogo-svyashhennomuchenika-klimenta/ (24.08.2011).

${ }^{15}$ According to the vita of St. Clement, for many years he was separated from his loved ones with whom he miraculously gets together again because of his faith.

$16 \mathrm{http} / / /$ new-sebastopol.com/news/novosti_sevastopolya/V_Sevastopole_otkryli_pamyatnik_svyatym_ravnoapostol_nym_Kirillu_i_Mefodiyu_FOTO_ (14.06.2008).

17 Savelii Ivanovic Buchkov, ca 50-year-old Bessarabian Bulgarian from Moldova who emigrated to Sevastopol after the collapse of the USSR, president of the Association of the Bulgarians in Sevastopol "Izgrev". Recorded 23.09.2009, Ekaterina Anastasova, Grigor Grigorov (from now on E. A., G. G.), Sevastopol.

$18 \mathrm{http} / / / \mathrm{www}$. regnum.ru/news/1545035.html (25.06.2012); see more: http://www.ukrinform.ua/rus/news/vadim_kolesnichenko_dovolen_chto_ den_drugbi_i_edineniya_slavyan_otmechaetsya_nakanune_prinyatiya_zakona_o_yazikah (25.06.2012); see also http://partyofregions.dp.ua/ node/126 (25.06.2010) (Last accessed 22.07.2015). The law was passed on July 3, 2012. This is the first law repealed after Evromaidan.

19 Petro Yatsik (1921-2001) is a major patron of the Encyclopedia of Ukraine, founder of the Ukrainian Institute at Harvard University (USA) and the Centre for the Study of Ukrainian history in the Canadian Institute of Ukrainian Studies at the University of Alberta (Canada). He also financed the construction of Ukrainian schools and churches in Brazil.

${ }^{20}$ In 2014, after the failure of President V. Yanukovych (Party of Regions), Metropolitan Agafangel resigned from the Odessa Rada (Parliament).

${ }^{21}$ See http://timer.od.ua/news/odesskij-mitropolit-agafangel-sravnil-lvovs-chechnej.html (07.06.2011) (Last accessed 22.07.2015).

${ }^{22} \mathrm{http} / / / w w w . m i s t o . o d e s s a . u a / o d e s s a-i-r e g i o n / 2008 / 09 / 12 / 13215 / p r a v o s l a v-$ naya-obshhestvennost-odessy-protiv-vstupleniya-v-nato.html (12.09.2008; site no longer accessible).

${ }^{23} \mathrm{Lvov}$ is considered the center of Western Ukraine and of the pro-western moods in the country. 
${ }^{24}$ http://www.pravda.com.ua/rus/news/2011/06/7/6275752/ (07.08.2011). (Accessed 22.07.2015).

${ }^{25}$ Bishop Agafangel, 24.05.2009, Odessa, rec. by E. A., G. G.

${ }^{26}$ Here I use materials from interviews held before a race dedicated to St. Cyril and Methodius between linguists and historians in the Odessa State University, short interviews with eight students in history (1-3 courses). Young people aged between 18 to 23 years, ethnic Bulgarians from Odessa area - 30.05.2009, Odessa, fieldwork diary, E. A.

${ }^{27}$ Georgy Prodanov, consul of the General Consulate of Republic of Bulgaria in Odessa. 27.05.2009, Odessa, rec. by E. A., fieldwork diary.

${ }^{28}$ X. X., 18-year-old boy, first year student, 30.05.2009, rec. by E. A., fieldwork diary.

${ }^{29}$ http://www.religion.in.ua/news/ukrainian_news/24271-odesskij-mitropolit-agafangel-nazval-evromajdan-smutoj-kuda-sobiraetsya-sila-ada. html (12.12.2013).

${ }^{30}$ Archpriest Andrei Novikov, secretary of the Odessa diocese, http://xerson. net/евромайдан-это-собрание-сил-ада-счи/ (Accessed 15.07.2015).

\section{Acknowledgements}

The article is a result of the project ДОО2-315/19.12.2008, No. 1/17.12.2010 "The Feast of the St. Cyril and Methodius - from the National to the European Spiritual Space", National Science Fund, Ministry of Science and Education of the Republic of Bulgaria.

\section{References}

Anastasova, Ekaterina 2005. "We are Bessarabians here". Identity, Tradition and Power in Southern Bessarabia. The Anthropology of East Europe Review: Central Europe, Eastern Europe and Eurasia, 24 (1), pp. 59-65.

Anastasova, Ekaterina 2012a. The National Festive Systems in the PostSocialist Space - between Past and Present. Kõiva, Mare (ed.). The Ritual Year, 6. The Inner and the Outer. The Yearbook of the SIEF Working Group on the Ritual Year. Tartu: ELM Scholarly Press, pp. 159-169.

Anastasova, Ekaterina 2012b. Identity of (Trans-)National Minorities in the NationBuilding Process (the Case of Ukraine). Hristov, Petko Petrov (ed.). 
Migration and Identity: Historical, Cultural and Linguistic Dimensions of Mobility on the Balkans. Sofia: Paradigma PH, pp. 269-278.

Anissimov, Vadim 2005. Zhitie suiyatyh ravnoapostol'nyh Mefodiya i Kirilla, Uchitelej Slovenskih. Odessa: Odesskii palomnik.

Begunov, Yuri 2006. Sv. Kliment Rimskii v slavianskoi traditsii: nekotorye itogi i perspektivy issledovaniia. Vizantinorossika, 4. Clementiana Nordica: Pochitanie Sv. Klimenta Rimskogo na severe khristianskogo mira. SanktPeterburg: Sankt-Peterburgskoe Obshchestvo vizantino-slavianskikh issledovanii, pp. 1-61.

Huntington, Samuel P. 1999 [1996]. Sblasakat na tsivilizatsiite i preobrazuvaneto na svetouniya [The clash of civilization and the remaking of world order]. Sofia: Obsidian.

Kerov, Valeri 2013. "Ukraina - Russ", "finno-ugorskie kolonii" i belorusskie natsional'nye obychai: obosnovanie natsional'nogo suvereniteta v ofitsial'nykh uchebnikakh po natsional'noi istorii Ukrainy i Belarusi. Vestnik Rossiiskogo Universiteta druzhby narodov. Seriia Istoriia Rossii 1, pp. 124-132.

Markevich, Arseni 1909. Ostrovok v Kazachei bukhte, kak predpolagaemoe mesto konchiny sv. Klimenta, papy Rimskogo. Izvestiia Tavricheskoi uchenoi arkhivnoi komissii, 43, pp. 106-114.

Simonova, Inna 1990. "Zagovorshchiki”. Iz istorii odnogo nesostoiavshegosia politicheskogo protsessa. Istoki (Al'manakh), 22, pp. 341-366.

http://ruskline.ru/analitika/2006/06/09/zagovorwiki

Sorochan, Sergei. 2013. Vizantiiskii Kherson (vtoraya polovina VI - pervaia polovina X vv. Ocherki istorii i kul'tury 3. Khar'kov-Moskva: Russkii Fond Sodeistviia Obrazovaniiu i Sodeistviia Obrazovaniiu i Nauke.

Spiridonov, Dmitri 1909. K voprosu o muchenii Klimenta, papy Rimskogo, v Krymu. Izvestiia Tavricheskoi uchenoi arkhivnoi komissii, 43, pp. 115-124.

Zaionchkovskii, Petr 1969. Kirillo-Mefodievskoe obshestvo (1846-1847). Moskva: Izdatel'stvo Moskovskogo Universiteta.

Tolstoi, Nikita 1988. Drevniaia slavianskaia pis'mennost' i stanovlenie etnicheskogo samosoznaniia u slavian. Istoriia $i$ struktura slavianskikh literaturnykh iazykov. Moskva: Nauka, pp. 128-140.

http://www.inslav.ru/images/stories/pdf/1988_Tolstoj.pdf 


\section{ELM Scholarly Press \\ SATOR 18}

http://dx.doi.org/10.7592/Sator.2017.18

\section{BALKAN AND BALTiCUM}

Current Studies in the Postsocialist Space

Edited by

Ekaterina Anastasova and Mare Kõiva

Tartu 2017 
Editors and compilers: Ekaterina Anastasova, Mare Kõiva Series "Sator" editor: Mare Kõiva

Language editors: Liisa Vesik, Lii Liin

Cover photo: Jaak Kikas, 2017 "Autumn in Tartu"

International committee

Tiiu Jaago (Tartu University); Reet Hiiemäe (Estonian Literary Museum); Mare Kalda (Estonian Literary Museum); Tarmo Kulmar (Tartu University); Nikolay Kuznetsov (Estonian Literary Museum); Aado Lintrop (Estonian Literary Museum); Emily Lyle (School of Scottish Studies in Edinburgh); Mirjam Mencej (Ljubljana University); Jonathan Roper (Tartu University); Marju Kõivupuu (Tallinn University); Ülo Valk (Tartu University); Tatjana Vladõkina (Institute of Udmurtian History, Language and Literarture, Izhkar); Irina Vinokurova (Institute of Karelian History, Language and Literarture in Petroskoi); Ergo-Hart Västrik (Tartu University)

Supported by Estonian Academy of Sciences, Bulgarian Academy of Sciences, the Centre of Excellence in Estonian Studies (CEES, European Regional Development Fund) and is related to research projects IRG 22-5 (Estonian Research Council).

\section{$\boldsymbol{C} E \mathbf{E} \times \begin{aligned} & \text { Centre of excellence } \\ & \text { in Estonian Studies }\end{aligned}$}

Series "Sator. Artikleid usundi- ja kombeloost", 18 http://www.folklore.ee/rl/pubte/ee/sator/sator18/

ISSN 1736-0323 (online)

ISBN 978-9949-586-58-5 (printed)

ISBN 978-9949-586-61-5 (online) ISSN 1406-2011 (printed)

DOI: 10.7592/Sator.2017.18

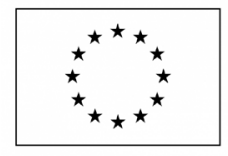

European Union European Regional Development Fund

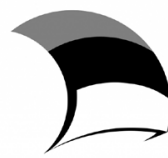

Investing in your future

\section{EUROPEAN UNION}

Regional Development Fund

Investing in your future
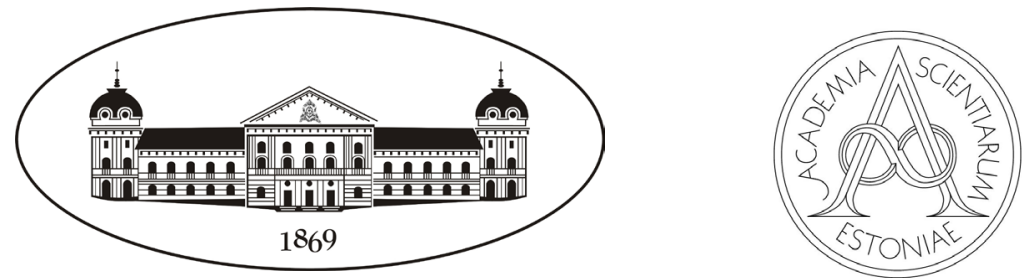


\section{Contents}

Preface

Mare Kõiva, Ekaterina Anastasova

CONSTRUCTING IDENTITY AND SOCIAL TIES

Ethnographic Studies on the Montenegrin

Festive Costume as a National Symbol

Sofiya Zahova

Social Ties of Bulgarians and Rudari in the Mediterranean Countries

Magdalena Slavkova

\section{RECASTING RELIGION AND \\ RELIGIOUS IDENTITY}

Contemporary Development of the Akyazili

Baba Tekke / St. Athanasius in Bulgaria

Yelis Erolova

Turkish Religious Identity in Bulgaria

94

in the Last Twenty-Four Years (1989-2013)

Mila Maeva

The Feast of Cyril and Methodius in Bessarabia and Crimea, Ukraine

Ekaterina Anastasova 
The Saints of Death in the Traditions

of the Balkan People

Rachko Popov

\section{CONSTRUCTING NEW SPIRITUALITY}

New Trends in the Study of Religion in Estonia -

Contemplations in the Grey Zone between

Religion and Science

Tõnno Jonuks

Constructing New Spirituality in Modernity -

the Case of the White Brotherhood in Bulgaria

Svetoslava Toncheva

Constructing Contemporary Periodical and

Occasional Rituals

Mare Kõiva

The Making of a Sacred Place:

221

An Example of Constructing Place Identity in the Contemporary Mentality

Reet Hiiemäe

\section{CHANGING TRADITIONS}

Bridge Over the Rainbow. Animal Burials and

Animal Cemeteries in Post-Socialist Estonia

Marju Kõivupuu

Simple Hide-and-seek at its Core: Play Features and the Game of Geocaching

Mare Kalda 